\title{
RELEVANCE OF KNOWLEDGE AND SKILLS ACQUIRED IN BUSINESS SCHOOLS - PERSPECTIVE OF SERBIAN EMPLOYERS
}

\author{
Biserka Komnenić ${ }^{*}$ \\ Novi Sad School of Business, Novi Sad, Republic of Serbia \\ Dragana Bolesnikov \\ Novi Sad School of Business, Novi Sad, Republic of Serbia \\ Isidora Milošević \\ Novi Sad School of Business, Novi Sad, Republic of Serbia
}

\begin{abstract}
In today's fast changing world, where knowledge relevant today can became obsolete tomorrow, higher education institutions are putting great efforts into empowering students to be able to meet demands of the employers from the start. Besides the phenomena of the fast-changing needs for new knowledge, which should be included in curricula, there is the challenge of training students to have adequate skills necessary for doing business in the $21^{\text {st }}$ century. Those skills, soft and generic should allow students to be able to cope more efficiently and effectively with the changes and demands of the contemporary business environment. The research subject of this paper is the perception of the business environment, i.e. employers, on the importance of knowledge and skills in the field of business economics that students of business schools acquire during undergraduate studies. The research goal is to gain a comprehensive and detailed insight into the opinion of the employers on the knowledge and skills they consider most important for the employment of undergraduate students of business schools. In addition, the aim is to articulate the types of activities and forms of cooperation with companies that, in the opinion of employers, can contribute to greater harmonization of the content of study programs in the field of business economics with the needs of practice. The research starts from the specifics of business economics studies in business schools, since this type of study differs from academic studies primarily in terms of training students in applied knowledge.
\end{abstract}

Key words: business schools, business study, knowledge, competences, skills

\footnotetext{
*bkomnenic@gmail.com
} 


\title{
RELEVANTNOST ZNANJA I VEŠTINA STEČENIH U POSLOVNIM ŠKOLAMA - PERSPEKTIVA SRPSKIH POSLODAVACA
}

\begin{abstract}
Sažetak: U današnjem svetu $i$ društvu zasnovanom na znanju, u kojem znanje relevantno danas već sutra može da postane zastarelo, institucije visokog obrazovanja ulažu velike napore kako bi osposobile studente da mogu što kvalitetnije i efikasnije da odgovore na zahteve poslodavaca. Pored konstantne potrebe poslodavaca za usavršavanjem u novim znanjima, a koja bi trebalo da nađu svoje mesto u nastavnim planovima $i$ programima, visokoškolske institucije se suočavaju $i$ sa izazovima osposobljavanja svojih studenata da ovladaju odgovarajućim veštinama neophodnim u savremenom poslovanju. Te veštine, meke i generičke, treba da omoguće studentima da se laǩ̌e nose sa promenama i zahtevima brzo promenljivog poslovnog okruženja. Predmet istraživanja ovog rada je percepcija poslovnog okruženja, odnosno poslodavaca, o značaju znanja $i$ veština iz oblasti poslovne ekonomije, koje studenti poslovnih škola stiču tokom osnovnih studija. Cilj istraživanja je sticanje sveobuhvatnog $i$ detaljnog uvida u mišljenje poslodavaca o znanjima $i$ veštinama koje smatraju najvažnijim za zapošljavanje studenata poslovnih škola. Pored toga, cilj je da se artikulišu vrste aktivnosti $i$ oblici saradnje sa kompanijama koje, po mišljenju poslodavaca, mogu da doprinesu većem usklađivanju sadržaja studijskih programa iz oblasti poslovne ekonomije sa potrebama prakse. Istraživanje polazi od specifičnosti studija poslovne ekonomije u poslovnim školama, s obzirom da se ova vrsta studija razlikuje od akademskih, pre svega zbog fokusa na primenjeno znanje.
\end{abstract}

Ključne reči: poslovne škole, poslovne studije, znanje, kompetencije, veštine

\section{INTRODUCTION}

The research subject of this paper is the perception of the business environment, i.e. employers, on the importance of knowledge and skills in the field of business economics that students of business schools acquire during undergraduate studies. Which knowledge and skills should business school students possess after graduation that will make them attractive for employment and that will enable them to get good jobs? What should the contents of the curriculum of business schools look like and which areas should they cover in order to be in line with the business practice? These are the questions that all 

PERSPECTIVE OF SERBIAN EMPLOYERS

business schools should ask themselves. It is crucial that business schools continuously review the value of their study programs from the perspective of employers in order to transfer to their students the knowledge and skills that meet the real needs of the business practice.

Therefore, the research goal is to gain a comprehensive and detailed insight into the opinion of employers from the territory of the Republic of Serbia Autonomous Province of Vojvodina, on the knowledge and skills they consider most important for the employment of undergraduate students of business schools. In addition, the aim is to articulate the types of activities and forms of cooperation with companies that, in the opinion of employers, can contribute to greater harmonization of the content of study programs in the field of business economics with the needs of practice.

Information and insights gained from research should help to propose relevant guidelines for harmonizing business study curricula with real needs of the business environment which is the main purpose of this paper. Also, the research of this paper should contribute to bridging the gap in the understanding of the concept of employability from the educators' and employers' perspective. Furthermore, the results of the research should provide guidelines to all business schools that educate students in the field of business economics as well as policy makers in the field of higher education and the labor market.

\section{LITERATE REVIEW}

For the last 15 years researches constantly show that demand of employers for employees, i.e. professionals with adequate and greater knowledge and skills is constantly increasing (Velez, 2012). Undergraduate studies still provide good jobs, but what is becoming increasingly apparent is the importance of choosing a major study program (Carnevale, Fasules, Huie \& Troutman, 2017). Also, having a bachelor's degree is not an automatic prerequisite for getting a good job, as was the case before. The modern knowledge-intensive economic environment makes the situation much more complex today. The research conducted by Forbes (Forbes) shows that $34 \%$ of graduates of undergraduate studies are employed at lower workplaces or in workplaces where they do not need their diploma (Cooper, 2017). Weissmann (2012) in his article emphasize that almost $54 \%$ of students who have acquired undergraduate diploma are either not employed or employed at lower positions (in jobs that do not require a diploma). These results indicate a re-examination of the value and quality of undergraduate diplomas and an urgent need to identify critical factors that will help students find employment adequate to their professional choice and diploma. It is noticeable that today certain general and specific professional 
knowledge as well as certain generic and soft skills acquired in undergraduate studies are a crucial factor for employment.

Many studies have examined the need for academics to continuously enhance the academic performance and skills level of business school graduates entering the workforce. The previous researches conducted in the area of business economics skill gap from the perspective of the employers almost all have the similar conclusions and that is that soft and generic skills are rated by employers more highly than hard business professional skills and knowledge. For example, research conducted by Pomorina, (2012), shows that above all, skills (general and specific) and knowledge most needed to be developed further in economics degree courses are one concerning written and oral communication skills, independence and creative thinking, the ability to apply what has been learnt and adaptability. Findings from the research conducted by Hodges and Burchell, (2003) about employers' views on importance and performance of business graduate competencies, suggest that employers are looking for knowledge potential, as much as they are looking for knowledge 'currency'. The research findings suggest that employers place greater importance on soft skills.

Luen (2008), in his study about curriculum gaps in business education analyzed stakeholder perception about skill gaps from the perspective of education "about business" and education "for business". He emphasized that the concept of 'about business' focuses on allowing students to study the role of business in society and the concept of 'for business' recognizes 'the vocational aspect of business. He stated that those two conflicting perspectives of business education are largely inherited from the traditional debate of a liberal versus a vocational curriculum in higher education. In the case of business education, the 'about business' and the 'for business' curricula focus on producing different types of skills: 'about business' focuses on soft skills, and 'for business' focuses on technical skills. The results of his research show, that in general, knowledge and skills to which potential employers attached highest mean values are one classified as for "about business". Also, of all the knowledge that falls into category "about busines" the highest mean value was attached to the soft skills. This means that potential employers considered soft skills of highest importance for business graduates who seek employment.

Study about employability and entrepreneurial skills of graduates conducted as part of the Europe Home project (2015), shows that interpersonal, communication and learning skills, for employers are most important. The results of this study also suggest that universities should focus on activities 

PERSPECTIVE OF SERBIAN EMPLOYERS

which should advance cooperation with companies in order to improve the employability of their graduates. A survey of critical knowledge and skills of business school graduates from employer perspectives conducted by Rassuli, Bingi, Karim and Chang (2012), indicated that interpersonal skills and the ability to work successfully in a team setting are specifically emphasized by the employers.

The study conducted by McMurray, Dutton, McQuaid and Richard (2016.), carried out to determine employers demand for business and management skills in the Scottish workforce indicates that, whilst technical skills continue to form the basis of a strong academic education, it is important for students to develop their soft skills. The study finds that effective communication skills, working together in groups and possessing relevant work experience are frequently cited by employers as key soft skills that are required to strengthen the employability of graduates. Also, when recruiting the graduates' personal attitude is, for employers, the most important factor. The results of the study also indicate that employers think that the business schools should engage in more intense dialogue with businesses, "so that it is clear for them who to contact around, work placements, recruitment and input".

In Qatar study (Alshare and Sewailem, 2018), dealing with potential gap between business students' skills/competences provided by businesses schools and the needs of the current job market results showed that business educators emphasize the importance of hard skills (e.g. critical thinking/problem solving, dealing with real world problems), but employers give emphasis to the soft skills (e.g. work ethics, communication/flexibility and adaptability). Denmark study conducted with the purpose to measure competencies of MSc graduate from Copenhagen Business School and employers' needs (Martensen and Grønholdt, 2009), indicate that employers' give particular importance to the personal and social competencies as well as to communication, business knowledge and the ability to create results as knowledge and skills which are decisive for the applicant getting the job. The graduate's professional competencies in the form of professional width and depth of knowledge were a prerequisite for being selected for an interview. The ability to participate and be involved as an individual and at the same time be capable of cooperating with others is seen as a forte of the current graduates by the employers.

Study conducted by West Virginia Department of Education (2019), with the purpose to explore employer demand and workforce shortages within five basic skill areas (including mathematics, English and language arts, technology, digital literacy, and soft skills) indicate that the largest gaps in demand vs. availability were observed in employer reports for soft skills and English and 
language arts skills. Results showed that all soft skills are in critical demand, with employers seeing limited supply of many of these skills in the workforce. Thus, employers clearly want educators to be aware of the importance of soft skills in the workplace. Study conducted by Andrews and Higson, (2008), analyses business graduate and employer perspectives of business graduate employability in four European countries (UK, Austria, Slovenia and Romania). Study finds that employers in all four countries expected business graduates to possess high levels of discipline specific skills synthesized with more generic interpersonal and communication competencies. Thus, in order to promote business-graduate employability on a pan-European scale, business schools across Europe need to make sure business graduates are equipped with more than hard business-focused skills and competencies (Andrews and Higson, 2008). All these studies have called for business education to be aligned with developments in the contemporary business practice.

\section{METHODOLOGY}

Since a comprehensive approach was applied in the research, its focus is on obtaining answers on the following questions: In the opinion of employers, which knowledge and skills in the field of business economics are most important for the employment of future graduates of business schools? Is there a mismatch between the knowledge and skills acquired in business economics studies and those required in practice? Are employers satisfied with the knowledge and skills that business graduates as their employees show in their jobs? Are companies interested in cooperating with business schools in order to improve the content of study programs and if so, in what form and with what intensity? In order to obtain answers to these questions, a questionnaire form was used as a research mechanism.

The creation of the questionnaire was done in several phases which included the creation of a pilot version of the questionnaire, then the detailed development of the questionnaire and finally the collection, organization and analysis of data. Based on the literature review, mutual consultations of the research team and consultations with the partner companies, a preliminary questionnaire was prepared. For the purpose of the possible comparation, previous research on the same topics which applied comprehensive approach was used as inspiration for designing the questionnaire. In designing the questionnaire, the research team relied specifically on the following previous research: Pomorina (2012); Luen, (2008); Rassuli et al. (2012); McMurray et al. (2016); Martensen and Grønholdt (2009). After relevant feedback from the partner companies, and additional 

PERSPECTIVE OF SERBIAN EMPLOYERS

consultations among research team members, the final version of the questionnaire was created.

The questionnaire consists of three main parts and a total of 37 questions. The first part of the questionnaire (A) is divided into two parts. The A1 includes information on the organization (name, headquarters, number of employees, ownership structure, primary activity, function performed by the respondent in the organization) while the second A2 includes questions related to the general opinion of the organization on employees coming from business schools with a bachelor's degree. Employers were asked about the reasons for hiring business school students and their satisfaction with their qualifications and acquired knowledge and skills. The second set of the first part of the questionnaire contains questions related to the opinion of employers about the need for cooperation with business schools, the ways in which they prefer this cooperation and the intensity of cooperation that they consider appropriate. The second part of the questionnaire (B) contains questions related to professional knowledge and competencies in the field of business economics and is divided into two sets of questions. The first set (B1) refers to the general knowledge and skills that, in the opinion of employers, business economics students should acquire when they graduate. The second set (B2) of questions refers to specific knowledge and competencies from separate disciplines that are most often taught in business economics, and which, in the opinion of employers, are necessary for a student to possess in order to be employed at internship level. The following disciplines are covered: accounting, finance, management, operational management, trade, marketing, quantitative methods, business research, business law, international business, entrepreneurial skills and ethics, information systems and foreign business language. The third part of the questionnaire $(\mathrm{C})$ is also divided into two sets of questions. The first $(\mathrm{C} 1)$ refers to the generic skills and second $(\mathrm{C} 2)$ to the soft skills that, in the opinion of employers, a graduate student of a business school should possess in order to be employed. Employers were offered to state the importance of 13 generic and 20 soft skills. Following the Luen, (2008) categorization of soft skills, they are classified into four categories: analytical skills, data collection skills, interpersonal skills, and work behavior.

The creation of such a comprehensive questionnaire was prompted by the desire to obtain as accurate and precise data as possible, which should serve to the improvement of the curricula in business economics. Most of the conducted researches on this topic lack comprehensive approach. Research based on shorter questionnaires usually contains summarized basic knowledge and skills or specific areas of certain knowledge and skills. Therefore, they don't allow the 
more precise insight needed to obtain more comprehensive and detailed insights which could improve future business economics curriculum design.

Structured questions with offered answers were used in designing the questionnaire. The second set of questions in the first part of the questionnaire combines questions in which respondents have the opportunity to choose only one or two offered answers and questions where the opinion of respondents is assessed using the Likert scale from 1 to 5. The second and third part of questionnaire (B and C) generates the opinion of the respondents through Likert scale from 1 to 5 . The geographical scope of the research is the territory of the Republic of Serbia Autonomous Province of Vojvodina. The research was conducted in electronic form. The electronically designed questionnaire was sent to 200 internet addresses of companies in the territory of AP Vojvodina. Questionnaires were available to respondents via a Google form link sent to them in an email containing accompanying information relevant to the survey in which they were asked to participate. Respondents' answers were automatically generated via the same link. The questionnaires were sent to companies with which the Novi Sad School of Business has established cooperation and to companies selected by the research team from the database of the Chamber of Commerce of Vojvodina. When selecting the potential sample, the goal was to cover different companies by size and sector affiliation as evenly as possible. Also, the goal was for the respondents to have some of the managerial functions (lower, middle and top management). The response came from 59 respondents, which for the purpose of this research is a satisfactory response rate (38\%) given the number of questions and the time required to complete the questionnaire. For the purpose of the analysis, descriptive statistics, mean value, percentage or absolute values were used. Privately owned organizations make up $71 \%$ of the sample, while $29 \%$ are state-owned organizations. The positions of the respondents - representatives of the companies included in the sample are as follows: Top management $68 \%$, middle management $16 \%$, and lower management $5 \%$. The share of small enterprises (up to 50 employees) in the total sample is $48 \%$, the share of medium enterprises (from 50 to 250 employees) is $25 \%$, while $27 \%$ of the sample are large enterprises (over 250 employees). Eleven industry sectors were generated from the sample: Education, Manufacturing, Agriculture, Forestry and Fisheries, Wholesale and Retail; Repair of motor vehicles and motorcycles, Financial and insurance activities, Accommodation and catering services, Water supply; Wastewater management, Control of waste disposal processes and similar activities, Transport and storage, Information and communication, Public administration and defense; Compulsory social security, Construction. The most represented 

PERSPECTIVE OF SERBIAN EMPLOYERS

sector in the sample is Manufacturing (27.1\%). In second place is Finance and Banking (16.9\%), then trade (10.2\%), information technology $(8.5 \%)$, tourism and hospitality $(5.1 \%)$, agriculture $(3.4 \%)$ and transport services $(3.4 \%)$. Other sectors are less represented in the sample. The organizations that make up the final sample represent different industries or sectors, and they are mostly privately owned. The presence of organizations by size in the sample is close to that reflected in the statistics at the level of the Republic of Serbia. In this respect, the representativeness of the sample for the purpose of the undertaken research is satisfactory.

\section{RESULTS}

Regarding the study programs from which employers are most interested to recruit business school graduates, the results of the research show that employers are most interested in hiring students who complete study programs in the field of finance and accounting (46\%). The second area of attractiveness for employers is the area of trade, for which $25 \%$ of employers declared themselves. In third place is business informatics (24\% of employers), and in fourth and fifth place is the field of marketing (19\%) and management (17\%). Given that the research sample covered 11 out of a total of 21 industry sectors taken from the official classification, the diversity of the sample in this regard can be considered satisfactory. Consequently, the results related to the interest of employers in hiring business schools' students from certain areas of business economics can be considered relevant.

Concerning the question about main motives of employers to hire business school graduates the results show that most of the employers (61\%) hire them for work positions that require their knowledge, while 33\% of them hire them because of their knowledge and understanding of economics. Regarding the question related to the satisfaction of employers with qualification of the recruited graduates most of the employers $(68 \%)$ believe that graduates of business schools are qualified to perform their jobs. However, it is important to point out that more than half of employers (54\%) only somewhat agree with the statement that graduate students employed by them in the last three years have all the necessary knowledge and skills to work in their organizations. This indicates a clear need for further improvement of knowledge and skills of business students.

Regarding the most important aspect that employers take into account when hiring graduates, results show that it is the level of specific knowledge and skills they possess and which are specific to the primary activity in which a particular employer is engaged. This aspect has the highest score of mean value $(4,26)$ 
The second most important aspect for hiring is the level of academic qualifications (mv 3,97). Also, for the employers, important aspect considered when hiring business school graduates is their possible practical experience in the field related to their organization ( $\mathrm{mv} 3,90)$. The results show that the exercising of practice during studies within the employer primary industry, and the experience of studying in a foreign land are considered as least important with mean values of 3,53, and 2,47 respectively.

When employers are asked what activities business schools should carry out in order to increase the employment opportunities of graduates, the greatest importance (with score of mean value 4,61) is given to the need to "introduce more practical tasks into the teaching process". Also, in their opinion, slightly less importance is attached to the "harmonization of the content of study programs with the real needs of the business practice" and to the "student's internships in companies in order to raise the level of their competencies necessary to perform real business tasks". Those two activities generate equal mean values of 4,60.

Regarding the question about cooperation between companies and business schools in order to advance students' knowledge and competence, results show that most organizations (78\%) are interested in cooperating with higher education institutions. Employers show the greatest willingness to organize professional practice for students (74\% of them), to participate in joint lectures and discussions organized by business schools (59\%), to design case studies from real practice, which will become part of the teaching process. (45\%). Also, employers are interested to participate in relevant research and surveys (42\%), to attend to organized meetings with management and professors of higher education institutions (40\%), and to cooperate with the Centre for Career Development (35\%). Regarding the intensity of cooperation between companies and business colleges, companies believe (80\%) that cooperation with business colleges should be continuous and in line with the situation, opportunities and current needs of employers and higher education institutions.

Concerning the question related to the importance of professional general and specific knowledge and competencies in the field of business economics from the aspect of the employers, results show that among 7 offered general competencies (skills), five of them gain mean value $>4$. Those are the "ability to organize, interpret and present quantitative data" (4.35), "ability to simplify complex problems - abstraction" (4.26), "ability to understand and interpret financial issues" (4,12), "ability to create a relevant business framework" (4.07), "ability to analyse economic, business and social issues" (4.01). On the other 

PERSPECTIVE OF SERBIAN EMPLOYERS

hand, employers attach the least importance to the "ability to think strategically" $(3,98)$ and "communicate economic ideas" $(3,98)$. As far as general economic knowledge is concerned (Knowledge of market functioning, Subsidies, Managerial economics, Possible connection of economic and other theorems, Macroeconomic variables, Social costs and benefits, Foreign trade flows, foreign trade policies, Opportunity costs, International trade institutions, National income and fiscal policy) employers believe that it is most important for graduate students to possess knowledge related to "Knowledge of market functioning" (4.39), "Subsidies" (3.81), and "Managerial economics" (3.75). On the other hand, employers attach the least importance to knowledge related to "International trade institutions" (3,36), "National income and fiscal policy" $(3,22)$.

\subsection{EMPLOYERS PERCEPTION ON IMPORTANCE OF THE SPECIFIC PROFESSIONAL KNOWLEDGE AND COMPETENCIES IN THE FIELD OF BUSINESS ECONOMICS}

The following areas of specific professional knowledge and competencies in the field of business economics were analyzed: accounting, finance, management, operational management, trade, marketing, quantitative methods, business research, business law, international business, entrepreneurial skills and ethics, information systems and business English (or some other foreign language). For detailed results about employer's perception of the importance of the specific knowledge and skills in the above-mentioned fields in business economics see Annex Table 1.

Accounting. Among seven offered types of knowledge and skills in the area of accounting, employer's attach the greatest importance to the "Understanding the basic principles of financial reporting", which is in the first place with an average mean value of 4,10 . This is followed by knowledge of the "Monitoring and summarizing business transactions", "Analysis and interpretation of financial balance sheets and accounts" and "Creating and analysis of the financial statements". Employers attach the least importance to the knowledge related to "Management accounting", "Cost accounting" and to "Preparation of tax reports" $(3,56)$.

Finance. Generated results show that in the field of finance, employers attach greatest importance to the knowledge related to "Measuring and monitoring financial performance", which with an average value of 3.75 is in the first place. The "Knowledge of the basic principles of banking, money market and international economy", with a slightly lower average mean value of 3.71, is in second place in importance. Employers attach the least importance to the 
knowledge related to the "Management of the investment portfolio" and "Security trading" when hiring graduates of business schools.

Management. Regarding management, the results show that employers attach greatest importance to the "Understanding the importance of decision-making" and "Communication" and to "Understanding the growth and development processes of companies". On the other side, the least importance is given to the "Understanding of the importance of organizational architecture" and the "Principles and concepts of modern management".

Operational management. Regarding the knowledge and skills in operational management, the results show that employers give the highest importance to knowledge and skills related to the "Application of tools and techniques of project management", as well as to "Understanding the principles and practices of continuous business improvement" and "Quality management". They attach the least importance to the knowledge related to the "Planning of start-up projects" as well as to the "Understanding the difference between production and service sector".

Trade. For employers, when hiring, most important type of knowledge in the field of trade is related to "Knowledge of factors that affect sales volume (such as prices, costs, supply, demand, customers, etc.)". The second most important is the "Knowledge of sales techniques", and the third is the "Knowledge of sales performance analysis methods". When hiring, employers attach the least importance to "Knowledge about customs and non-customs barriers", as well as to "Knowledge about the importance of the business environment and technology in national trade".

Marketing. When it comes to the importance of knowledge and competencies in the field of marketing, employers, when hiring business graduates, mostly value "Knowledge of customer behaviour". The second and third place in importance belongs to the knowledge related to the "Understanding the function of the marketing in the organizations", and knowledge related to the "Understanding of the primary role of marketing in contemporary society". The least importance is given to the "Knowledge of international marketing.

Quantitative methods. In respect of the knowledge and skills related to quantitative methods, the results of the research show that for employers the most valuable knowledge is one related to "Digital marketing principles". Also, they highly value "Knowledge of basic concepts of data collection and probability distribution". The least importance is attached to the "Application of regression analysis to solve business problems". 

PERSPECTIVE OF SERBIAN EMPLOYERS

Business research. In the area of business research, the results show that employers attach greatest importance to the "Ability to draw conclusions and recommend relevant guidelines for solving a particular business problem". In second place is the "Understanding of the purpose and process of business research". As the least significant type of knowledge related to business research, employers rank the knowledge related to "Use of alternative research methods for data collection".

Commercial law. Regarding the knowledge in the field of business law, first ranked type of knowledge is one related to "Understanding the laws of the national business environment", then "Understanding the principles of company law", while the least significant is the "Understanding of business management principles and practices".

International Business. As far as international business is concerned, employers attach greatest importance to "Knowledge of the reasons for organizations to enter foreign markets", "Modern trends in international business" and "Awareness of the importance of cultural differences for international business". On the other hand, they attach the least importance to knowledge related to the "Economic effects of international trade for the national economy" as well as knowledge related to the "Importance and role of international trade institutions and trade unions".

Entrepreneurship. The results of the research regarding the importance that employers attach to knowledge and skills related to entrepreneurial skills and ethics show that for the employers the most important is the "Awareness of ethical issues faced by business people", while "Understanding the business development process from beginning to end" is considered less significant.

Information systems. In the field of information systems, employers attach the greatest importance to "Recognizing IT components, such as hardware, software, networks, data transmission and databases". In second place is the "Knowledge and understanding the wider application of information systems". As the least significant type of knowledge employers rank one related to the "Application of relevant methodology, tools and techniques for the optimal use of information technology".

Foreign business language. Regarding knowledge of foreign business languages, employers attach the greatest importance to the possession of "Fluent written communication, "Fluent oral communication and presentation, as well as to the "Ability to understand, write and communicate various business reports and documents". All three mentioned types of knowledge share the first place with the mean value of 3.94. On the other hand, employers attach 
the least importance to the knowledge related to "Interpretation of diagrams, tables and graphs".

\subsection{EMPLOYERS PERCEPTION ON IMPORTANCE OF THE GENERIC AND SOFT SKILLS}

The third part of the analysis is focused on the importance of certain generic and soft skills for the employment of graduates of business schools. For detail results about employer's perception of the importance of the generic and soft skills see Annex - Table 2.

Generic skills. The results show that out of a total of 13 offered generic skills employers attach the highest value to the "Ability to cooperate and work efficiently with others" (mv 4.54), as well as to the "Ability to solve problems independently" ( $\mathrm{mv}$ 4.51). Also, employers believe that it is extremely important for employed graduates to have a "Developed ability of clear spoken and written communication" (mv 4.49) as well as the "Ability to learn quickly" (mv 4.45). Employers consider "Self-criticism", "Awareness of socio-cultural differences" and "Research skills" the least important.

Soft skills. Regarding the Soft skills, it can be concluded that of all the analytical skills, employers attach greatest value to the "Ability to adopt a broader perspective", i.e. the "Ability to analyse and synthesize" (mv 4.07). In terms of data collection skills, the "Ability to adapt to new situations was rated the best" ( $\mathrm{mv}$ 4.53). In addition, of all interpersonal skills, employers value "Teamwork" ability the most (mv 4.72), while "Task performance efficiency" is the best rated skill related to work behaviour ( $\mathrm{mv} 4.79)$.

\subsection{KNOWLEDGE AND SKILLS WITH HIGHEST MEAN VALUES GIVEN BY EMDPLOYERS}

The analysis of research results based on the parameters of the highest mean values, i.e. those $=$ or $>4$, provides insight into the attitude of employers about the types of knowledge and skills that they consider most important for the employment of business school students. Out of a total of 131 offered types of knowledge and skills (general and specific professional knowledge and skills as well as generic and soft skills), the employers gave 43 of them average mean value equal to or greater than four $(=;>4)$. For detail list of these types of knowledge and skills see Annex- Table 3.

What is interesting is that when we look at the structure of the group of knowledge and skills with a mean value $=$ or $>4$, it is dominated by generic and 

PERSPECTIVE OF SERBIAN EMPLOYERS

soft skills. 13 generic skills and 25 soft skills belong to this group. Out of a total of 13 offered generic skills, 11 of them have a mean value greater than 4 , while out of a total of 25 soft skills, 21 of them have a mean value greater than 4 .

As far as general and specific professional knowledge and skills are concerned, out of a total of 96 types of knowledge and skills belonging to this group (18 types of general knowledge and skills and 78 specific knowledge and skills), only 11 of them have an average value $=$ or $>4.00$. These include six general professional types of knowledge and skills and five specific professional types of knowledge and skills. General knowledge and skills that are assessed with mean value $=$ or $>4.00$ include general professional knowledge related to "Knowledge of market functioning" (mv 4.38) and five general professional skills: "Ability to organize, interpret, present quantitative data" ( $m v$ 4.35), "Abstraction" (mv 4.26), "Understanding and interpretation of financial issues" (mv 4.12), "Ability to create a relevant business framework" (mv 4.07) and "Ability to analyse economic, business and social issues" (mv 4.01). Five specific types of professional knowledge and skills with mean value $=$ or $>$ of 4 , includes two types of knowledge in the field of accounting (Understanding the basic principles of financial reporting and Monitoring and summarizing business transactions), two types of specific knowledge in the field of management (Understanding the importance of decision making and communication and Understanding the process of growth and development of the company) and one type of knowledge in the field of trade, which refers to the "Knowledge of the factors influencing sales (prices, costs, supply, demand, customers ..)".

\section{CONCLUSION}

This research has applied a comprehensive approach in an effort to generate results that provide insight into all relevant types of knowledge and skills that are perceived to be important for the employment of graduate students in business economics. It also starts from the specifics of business economics studies in business schools, since this type of study differs from academic studies primarily in terms of training students in applied knowledge. For this reason, in addition to identifying the opinion of employers on the most important types of knowledge and skills in the field of business economics, this research also gained insight into the opinion of employers on the quality of employees coming from busines schools, their competences and preparedness for the work tasks. Also, insight was gained into the opinion of employers on the need for cooperation with business schools, the ways in which they prefer this cooperation and on the intensity of cooperation that they consider appropriate. 
The results of the research show that employers are most interested in hiring students who are completing study programs in the field of finance and accounting. "To perform jobs that require their knowledge" is the main motive that employers have when hired graduate students from business school. Most employers believe that graduates of business schools are qualified to perform the jobs they have be assigned. However, it is important to point out that more than half of employers only partially agree with the statement that graduate students employed by them in the last three years have all the necessary knowledge and skills to work in their organizations. This indicates a clear need for further raising the level of knowledge and skills of business schools' students. Also, the results show that the most important aspect that employers take into account when hiring business school graduates is the level of knowledge and skills they possess and which are specific to the primary activity in which a particular employer is engaged. In addition, employers consider the level of academic qualifications to be extremely important when hiring, as well as the practical experience that graduate students have in the field related to their primary activity.

Employers believe that in order to increase employment opportunities for graduates, and to improve knowledge transfer, the focus should be on introducing a larger number of practical tasks into the teaching process. In addition, employers believe that it is necessary to harmonize study programs to a greater extent with the real needs of the business practice. Their opinion is that in order to raise the level of competencies necessary to perform business tasks, it is necessary to devote more time to professional practice. Most of the sampled organizations are interested in cooperating with business schools in order to participate in the improvement of knowledge and competencies that are transferred and in which students of business schools are trained. Employers are ready to cooperate mainly through organizing internships for students, then by participating in joint lectures and discussions organized by higher education institutions, and by cooperating in designing case studies from real practice, which will become part of the teaching process of business schools. Companies believe that cooperation with business schools should be continuous and in line with the situation, opportunities and current needs of employers and higher education institutions.

The results of the research that refers to the survey of employers' opinions on the importance of certain types of knowledge and skills for the employment of future business school graduates highlight the importance of soft and generic skills. When you look at the structure of the group of types of knowledge and 

PERSPECTIVE OF SERBIAN EMPLOYERS

skills with mean value above 4 , out of a total of 38 offered generic and soft skills, 32 of them belong to this group. Furthermore, the first ten types of knowledge and skills that employers rated with the highest grade with a mean value ranging from 4.79 to 4.51 are eight soft skills and two generic skills. Thus, the results convincingly indicate that soft skills are of the greatest importance for employers. Among the most important are those related to work behaviour, i.e. efficiency in performing tasks, ability to meet deadlines, commitment to goals, ethics, initiative and perseverance in carrying out tasks. There are also soft interpersonal skills such as the ability to work in a team, and the ability to facilitate communication and cooperation, and soft skills from the group of data collection skills, which refers to the ability to adapt to new situations. Of the generic skills, two of them are in the top ten and they are the ability to solve problems independently and the ability to work effectively with others.

Regarding general professional and specific knowledge and skills, out of a total of 96 types of knowledge and skills belonging to this group (18 types of general knowledge and skills and 78 specific types of knowledge and skills), only 11 of them have an average value equal to or higher than 4.00. Therefore, the results of this research confirm the conclusions of previous researches in this area (some of them mentioned in the literature review), which indicate that modern employers, when hiring, attach the greatest importance to soft skills. Soft skills generally involve a combination of social and emotional intelligence as well as attitudes and abilities that, together with complementary general and specific professional knowledge, enable coping in the work environment, good cooperation with others, efficiency and productivity at work and achieving more difficult business tasks. Generic skills are transferable skills of a higher order. They generally refer to skills such as the ability to solve problems independently, patience, adaptability, flexibility, creativity, application of knowledge in practice and as such are desirable today in almost all jobs and specific areas of business. Soft and generic skills are extremely important for today's employers as most of today's jobs integrate thinking and acting, requiring flexibility, initiative, and the ability to take on a variety of tasks. Therefore, the results of research that indicate the greatest importance of these skills are not surprising. Employers consider general and specialist knowledge and skills in the field of business economics as something that is necessary to possess in order to obtain a diploma in business economics. Also, they are aware of the fact that it is certainly easier for educators to transfer professional knowledge compared to the skills and abilities associated with soft and generic skills. These findings also suggest that employers in general give greater 
importance to skills which refer to the concept "About business" rather than "For business". They are aware of the fact that in contemporary fast changing society possessing soft skills represents potential long-term human capital.

Therefore, the results of the research imply one very important thing, and that is that business schools, within their methods of knowledge transfer, must insist on approaches that, along with the transfer of general and specific knowledge and skills related to business economics, enable students to acquire important generic and soft skills. For example, the ability to work in a team and work effectively with others can be acquired by insisting on teamwork in solving certain course tasks, case studies and the like. The ability of clear spoken and written communication can be developed by insisting on writing and presenting essays in preparation for listening to upcoming material or by testing the knowledge of already presented material in the form of writing and defending seminar papers. Also, the ability of analysis and synthesis as well as critical thinking should be constantly encouraged through an interactive process of knowledge transfer where as an imperative should be imposed a way of teaching that includes constant discussion and presentation of different opinions. In addition, through more close cooperation with partner companies, through student internships, working on project tasks designed together with companies, soft skills can be acquired.

Contributions and limitations of research. The contributions of this study are multiple. Most studies that examine the attitudes of the employers about the importance of certain knowledge and skills in the field of business economics and their expectations from graduates of business schools do not provide detailed and comprehensive information on which business schools could draw up their guidelines for creating the content of their study programmes which would be more in line with the real needs of the business practice. Due to the fact that research on this issue at the national and global level lacks a more comprehensive approach, with more precise and deeper insights, this study contributes to the research in this field by providing detailed insight into knowledge and skills which business schools should either include in the contents of their curricula or pay more attention to them, thus filling the existing gaps in the research literature dealing with the issue of education in the field of business economic.

In addition to the academic contribution, the results of this study are of great practical importance given that business schools can use them to identify possible discrepancies between the knowledge and skills taught at their institutions and those really needed by employers. Also, the results of the study 
can serve as specific guidelines for creating study programmes and their content in a way that will more accurately identify the real needs for knowledge and skills in certain business areas. This study can also help policy makers in the field of higher education and the labour market in gaining more precise insights into the needs of the business environment for certain knowledge and skills in business economics, thus enabling them to plan, finance and support activities related to improvement of the content of business studies, whether those related to three-year studies or those that would be in the form of shorter courses or training programs. Also, the results of the study provide very specific guidelines for the activities of the Centre for career development in business schools, in terms of focusing on organizing workshops and trainings related to generic and soft skills that employers most value.

The study has its limitations and they relate primarily to the sample size. It would certainly be good in the future to conduct research on a larger sample in order to gain the most accurate and objective insight. Furthermore, as the present study was already extensive enough, it did not include some types of knowledge and skills that may have deserved to be included, and which would have helped to build an even more comprehensive picture.

\section{REFERENCES}

Alshare, K., \& Sewailem, M. F. (2018). A gap analysis of business students' skills in the $21^{\text {st }}$ century: A case study of Qatar. Academy of Educational Leadership Journal, 22(1), 1-22.

Andrews, J., \& Higson, H. (2008). Graduate employability, 'soft skills' versus 'hard' business knowledge: A European study. Higher education in Europe, 33(4), 411-422.

Carnevale, A. P., Fasules, M. L., Bond Huie, S., \& Troutman, D. R. (2017). Major matters most: The economic value of bachelor's degrees from the University of Texas System.

Cooper, P. (2017). New York fed highlights underemployment among college graduates. Forbes. Retrieved from https://www.forbes.com/sites/prestoncooper2/2017/07/13/new-york-fedhighlights-underemployment-among-college-graduates/\#45d30bb740d8.

Hodges, D., \& Burchell, N. (2003). Business graduate competencies: Employers' views on importance and performance. International Journal of Work-Integrated Learning, 4(2), 16. 
Luen, W. K. (2008). Curriculum Gaps in Business Education: a Case Study of Stakeholders' Perceptions (Doctoral dissertation, Thesis submitted for the degree of Doctor of Education at the University of Leicester).

Martensen, A., \& Grønholdt, L. (2009). Quality in higher education: linking graduates' competencies and employers' needs. International Journal of Quality and Service Sciences.

McMurray, S., Dutton, M., McQuaid, R., \& Richard, A. (2016). Employer demands from business graduates. Education+ Training.

Pomorina, I. (2012). Economics graduates' skills and employability. Economics Network.

Rassuli, A., Bingi, P., Karim, A., \& Chang, O. (2012). A survey of critical knowledge and skills of business school graduates: employer perspectives. The Journal of International Management Studies, 7(2), 1-6.

Velez, A. (2012). Preparing Students for the Future-21stCentury Skills. Southern California: UMI.

Weissmann, J. (2012). 53\% of Recent College Grads Are Jobless or Underemployed-How?. The Atlantic, 23.

Note: This paper is a part of the research project "Analysis of the real needs of the economy of Autonomous Province of Vojvodina for knowledge and competencies in the field of business economy" financed by the Provincial Secretariat for Higher Education and Scientific Research of Autonomous Province of Vojvodina, Republic of Serbia.

Delivered: 08.12.2020.

Accepted: 05.02.2021

\section{ANNEX TABLES}

